\title{
Rifle Trajectories and Rifles
}

\section{Arthur Walker Esq.}

To cite this article: Arthur Walker Esq. (1862) Rifle Trajectories and Rifles, Royal United Services Institution. Journal, 6:24, 436-446, DOI: 10.1080/03071846209418200

To link to this article: http://dx.doi.org/10.1080/03071846209418200

$$
\text { 曲 Published online: } 11 \text { Sep } 2009 .
$$

Submit your article to this journal $\pi$

Џll Article views: 6

Q View related articles $₫$ 


\title{
RIFLE TRAJECTORIES AND RIFLES.*
}

\author{
By Antutr Watsen, EsQ., 79th Highlanders, Lientenant Instructor, \\ School of Musketry, Fleetrood.
}

Until the last few years the small-amms practice, so called, of the British army has been a farce; it is notorious that not one man in a thousand of Wellington's troops had erer learnt to shoot, and it was held that of every 250 bullets fired, 249 were thrown array.

The modem improvement in small arms has however changed all this : the Rifleman of 1862 , denling death at a distance of 1,000 yards, is a very different being from the soldier of 1800 , with his musket lilling once out of 250 times at a distance of 100 yards, and the inproved weapon of our day has, a minimum calculation, rendered the fire of infantry soldiers fourfold more effectire than it formerly was; always provided, however, that the training of the soldier in whose liands this weapon is placed, has been such as will enable him to elicit or derelope its full power; for, whaterer the range and accuracy of a rifle may be, it obviously loses very much of its ralue and scope if placed in the hands of $a$ man unskilled in its use. For, just as highly improved machincry involves increased intelligence on the part of the mechanic and engineer, and as the introduction of steamploughs and reaping-machines in farming necessitates a superior description of agricultural labourer, so in like manner the introdnction of the rifle into our service demands on the part of the soldier a certain knowledge, which can only be imparted to him by means of n special training; to place the riflo of the present day in the hands of the " nipe-clayed antomaton " of former days, would be an anachronism and inconsistency.

In this course of musketry training, there is perhaps no portion of it nore absolutely essential to men armed with the Enficld rifle than "judging distance." For the most part we are too apt to rest satisfied with becoming tolerably good shots, at targets placed opposite us, at fixed and known distances, forgetful that in the field of active service-which after all is the only proper medium throngh which to regard the efficiency or non-efficiency of the rifleman or soldier-unless lic can at least judge the distance at which the enemy is from lim with a certain proximate accuracy, and adjust his sight accordingly, he might almost as well for all practical purposes be armed with the smooth-bore gum of a century back. A striking illustration of this is given by a writer in Blackwood's Magazine, in his description of the equipment of the Garibaldians, immediately prior

* Communicated 31 May, 1862,-Ev. 
to the battle of Melnzzo, in Sicily. He there states: "For the most part the force was armed with 'Enfields,' but few knew how to derelope the nse of that deadly weapon, the sights being deemed a superiluity." The question naturally suggests itself to the reader, Why were the sights thus deemed superfluous? and the obrious answer arises, that it was mainly, if not entirely, owing to those men, thus : 1 s...ed, being utterly ignorant of and deficient in the porrer of judging distances.

We witness now erery year at Wimbledon a magnificent spectacle of rifle-shooting; but take some of those crack Wimbledon shots, and place them in an open country, in an Indian jungle, or a Clinese rice-ficld, and, without telling the distance, ask them to hit an object the size of a man, some considerable way off, and they will at once frankly admit their inability to do so. Jndging distance is ignored at Wimbledon, and perhaps for divers reasons necessarily so ; but so long as we have a rifle furnished with a back sight requiring adjustment, or retain any pretension to be practical soldiers, we cannot ignore its absolute necessity.

Tho question as to whether a soldier can be trained to judge distances or not, has long since been affirmatively determined, and the accumulated returns at the Hythe Scliool of Minsketry establish beyond all doubt that the majority of soldiers, provided they have average cyesight and an ordinary amount of intelligence, may acquire a proficiency in judging distance sufficient for all practical purposes.

Having thus indicated the requirement existing for crery one armed with the Enficld Rifle being alle to judge distance with a certain degree of approximate accuracy, I shall now endearour to slow why it is this necessity exists, and I shall also essay an explanation of the general principle upon which the present system of teaching judging distance is based.

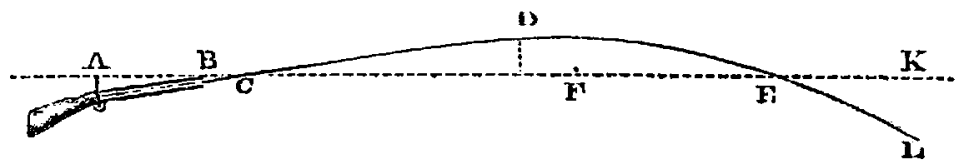

In the above figure, let the line C D E L represent the trajectory of a bullet, and let the line $A \mathrm{~K}$ illustrate the line of sight. If re consider the relative position of the trajectory here towards the line of sight, it will be observed that for a short distance beyond the muzzle of tho supposed gum the trajectory is below the line of sight, it then cuts it at the point $\mathrm{C}$, and I may remark that this point of intersection is of no value in the consideration of the firing of arms; beyond the point $C$, the trajectory gradually rises till it culminates at $D$, and here $I$ may parenthetically remark the point of culmination in the Enfield trajectory, where it obtains its meridian height, is a very little more than mid-way at short ranges, and nearly tro-thirds of the entire distance at the longer ranges.

After culminating, the trajectory makes a gradual clescent till it again cuts the "line of sight" at the point $E$, this point of second intersection of the trajectory with the line of sight is of important interest. 
Abroad, this constitutes what is termed the "point blank;" the English acceptation of this term is, howerer, entirely different. Point blank, according to our interpretation, consists in tho first graze made by a bullet fired from any pieco the axis of which has been laid parallel with the horizon; as in Tight of a projectile can, howerer, be fully explained withont making twi of a tom so ambiguous and liable to be misconstrued, I shall dispense with further allusion to it. It rill be sufficient, at present to direct your observation to tho fact that $t_{0}$ lit a small object, an apple or oyster-shell, that apple or oy'ster-shell must be placed in the direction of our line of sight exactly where the trajectory, which it must be borne in mind alwars indicates the actual course of the bullet, makes its sccond intersection with the line of sight; for by inspecting the foregoing figure it will be seen that if mo vish to strike an object $F$ between the point $\mathrm{E}$ and the muzzlo of the gun and aim directly at it, the ball will pass above it a ccrtain distance $F D$ and it will be the same for all points betreen $\mathrm{C}$ and $\mathrm{E}$ : and, again, if wo wish to striko an object $\mathrm{I}$ beyond the sccond point of intersection and aim dircetly at it, the ball wonld pass below it a certain quantity, $\mathrm{H} \mathrm{K}$, and so for all points bejond $E$. Hence it appears that, in order to hit an object, it is necessary that it should be precisely at the point of second intersection of the trajectory with the line of sight.

But fortunately for us as practical soldicrs tho objects we are tanght to aim at and hit possess a consilcrnble degree of height, thus the arerage height of an infantry soldier is assumed to be six feet, and that of a cavalry soldier on horse-back cight feet six inches, hence it follows that not only should we hit these objects when at the point E, but equally so vithin certain limited distances on either side of that point.

Let us gire this a definite application. If the Enficld rifle is taken, and the sighting or elevation for 100 yards made use of, matters are so arranged, that if aim be correctly taken, the bullet would pass through the centre of a man's body at 100 yards distance; but as tho the bullet, when fired with this eleration, never attains a greater height than 4 fect 6 inches, where in fact it culminates-and as it docs not make its first graze or strike the ground till 195 yards from the firing point-it follows that not only will the bullet hit a soldier in the waist-belt when standing a hundred yards off, but it rould hit him equally somervhere higher, even were he to adrance to the muzzle of the piece, and on the other hand, eren were he to get $\mathbf{1 9 5}$ yards off, he would there be hit in the fect.

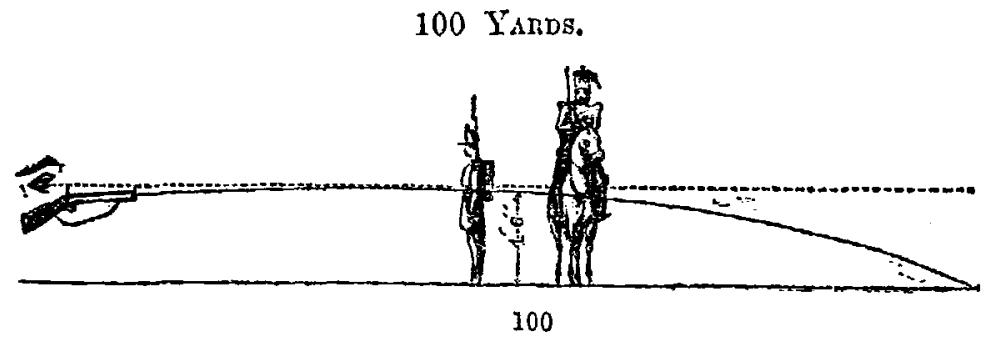

Thus appears that practically no one could stand in the direction 
the line of sight for a distance of 195 sards with impunity, and this distance constitutes what is techically termed the "dangerous space" (for an clevation of 100 yards.)

With the cleration duc for 200 yards, tho bullet culminates at a height of 5 feet 4 inches from the ground, and makes its first graze at a distance of 280 yards from the muzzle, so that re here again liave Infantry under the power of our rifle throughout the entire flight of the bullet.

\section{Yards.}

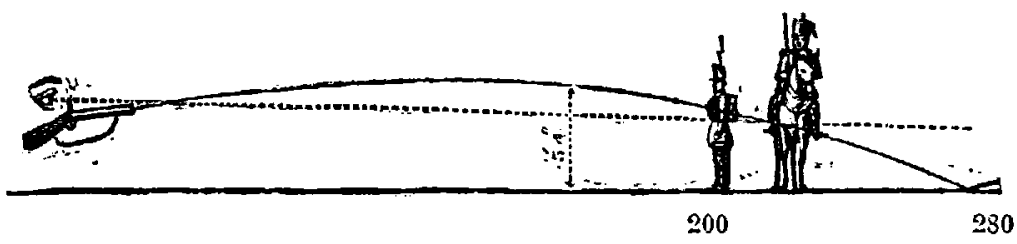

Mrorcover it is worthy of remark, that, as the bullet rebounds or ricochets at rery nearly the same angle as that with which it strikes the ground, the angle of incidence and reflection being equal; and as at this and other short ranges, that angle is comparatively low and flat, so to speak, it follows that we may with a certain degree of prudence, haring due regard to the nature of the ground, calculate on an effectire ricochet-fire of at least some 20 or 30 yards further, so that practically it may be arerred, that if the sight is adjusted to 200 yards, and the rifle be held straight, some part of a man must be lit throughout a distance of 300 yards, irrespective of any further porrer of judging distance than is required to tell tho difference between 1 yard and $300-n$ useful fact this to be bome in mind by a sentry on outlying picket, if taken by surprise.

So much for the trajectory in reference to Infantry soldiers at those tro ranges; small reflection is required to perceire that Caralry would fare no better, but rather a degree worse, inasmuch as they wonld be equally under the influence of our bullet throughout its flight, while at the same time their greater height affords a larger target for aiming at, and the disadrantage of this greater licight makes itself eren more apparent to us, in reference to the trajectory, at the next and following distance of 300 ynards.

With the eleration for 300 yards, the culminating height of the bullet is 7 fect, and its first grazo 370 yarrls from the firing point, giving as a dangerons space for the Caralry soldier on horseback, with an average height of 8 feet 6 inches, 370 yards; and, considering the nature of the ground over which Caralry must of necessity act, and their greater height, it certainly would not be too much to assume that we may depend on the effect of ricochet fire for some 30 yards beyond the first graze; hence re arrive at the important conclusion that, admitting yon are no judge of distances, all that an Infantry soldier need do if attacked by Caralry is, to adjust his sight to 300 yards, and calmly wait till his mounted cnemy come within the to him fatal distance of 400 yards, in order to make him bite the dust, for such is tho lowness of our trajectory here, that you cannot miss him. 
Never did lmowledge more clearly constitute porrer than this; and had the 93rd Highlanders, or rather those who commanded them, but known this little fact on the morning of the 24th October, 1854, we might have been spared the disastrous sequel of the Light Caralry charge.

As a proof that I am not at all exaggerating the effect of ricochet fire at those distances, I may adduce the melancholy instance of the death of Captain Collins of the 26th regiment, from the ricochet of a bullet fired at the Curragh of Kildare. "A party of soldiers were firing volleys at the usual distance of 400 yards, when, as Captain Collins ras crossing the range in rear of the target-butt, at a distance of some 1,100 yards from the firing party, a bullet, doubtless fired with more than the necessary elevation, passed over the butt, making its first graze at about 900 yards from the firing point; it appears then to have made a ricochet of some 200 yards, striking Captain Collins in the heart and producing instant death." That the bullet had first ricocheted was proved by the fact of blades of grass being found imbedded in the lead.

Thus far it must be very satisfactory and consolatory to such as would seek a "royal road" to judging distance, to lnow that we are not absolutely dependent upon every soldier knowing the exact distance of an object, for from the height of the trajectory and its comparative flatness at the ranges to which I lave just referred, we are, to a certiin extent, rendered independent of judging distance.

We now arrive, however, at a point where the necessity of being able to judge distance with a greater degree of accuracy becomes clearly palpable, for as our bullet attains a culminating height of 7 feet when fired with the elevation due to 300 yards, it follows that during a portion of its flight it would manifestly pass harmlessly orer the hend of a soldier, even were he a giant 6.99 feet in height.

It has been determined by carcful experiment, that the bullet would first catch an Infantry soldier in the hair of the head as it were, at 225 yards from the firing point; at 300 yards, provided aim lad been properly taken, it would strike a man in the waist-belt; and at 370 yarls it would strike him somewhere in the fect.

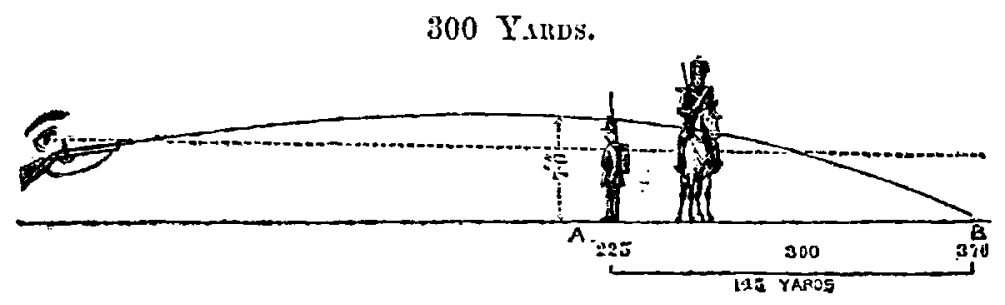

Our dangerous space, therefore, is now limited to the distance betwen $A$ and $B$ in the abore figure, that is 145 yards.

With the riew of showing that the necessity of judging distance increases with the range, let us proceed at once to trace the course of the trajectory at 600 yards. The bullet now reaches a leight of 20 feet before culminating; it first catches an Infantry soldier in the crown of the head 
at $a$ distance of 565 yards, and strikes him in the heels (makes its first graze) at a distance of 635 yards.

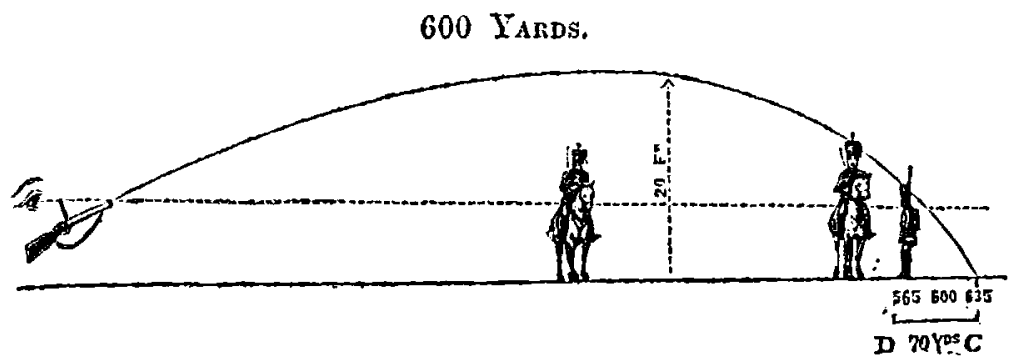

Our dangerous space is thus considerably curtailed, lying merely between $\mathrm{D}$ and $\mathrm{C}$, equivalent to a distanee of 70 yards. The practical inference to be deduced from this is, that to fire with accuracy the soldier should be capable of appreciating the distance of objects so as not to commit an error greater than $A B$ in the first instance, and $D C$ in the second, that being the respective margin permissible in either case for misappreciating the actual distance. In the case of Caralry, in the latter instance, the margin, oring to their greater height, would be slightly more.

In teaching how to judge distances, the recruit is instructed first to take note of the size and appearance of men, placed opposite him, at fixed, known distances; he has as it were to draw a picture in his mind's cye, of these "fixed points;" to make, so to speak, n mental photograph of them, so that afterwards when he is called on to judge of men at mknown distances, by a process of inductive comparison, by looking mentally on that picture and on this, he arrives at a correct conclusion as to the number of intervening yards. At 100 yarls, the linenments of the face can no longer be discemed; the buttons seem to form a continuous line; the number or ornament on the cap is scarcely discernible from the band, but the different parts of the body: the movements of men indiridually, and the form and colour of the uniform, are perfectly distinguishable. At 200 yards, the buttons, as buttons, are invisible, and the face looks like a whitish ball under the cap, but the colour of the uniform, the badges of shakos, and cartouch boxes can still be distinguished. At 325 yards, the rifle at the shoulder and the different parts of the uniform are discernible: objects at this distance are said to have an apparent size of about one third their actual size. At 400 yards, oljects liave an apparent size of about a quarter their actual dimensions, the direction of the march of Infantry, and the morement of their muskets can be distinguished, and so on. The recruit is, at the same time, warned that all inductions of this chartenter require modifientions, dependent on his own cyesight, the position of the sun, the state of the atmosphere, and the background. $\Lambda$ body of Infantry marching with the sum opposed to them, send out strong and constant rays of light, in the direction in which they are marching; when the sun is behind them, no light is sliown. In foggy or clondy weather, oljects haring less light falling on them appear more distant than they 
are, whilst in clear sunshiny days, being much more lighted up, the details are more clearly visible, the olject appearing nearer than it is in reality.$\Lambda$ man placed before any ligh building, high tree, $\& c$., will appear smaller and more distant than he would appear under other circumstances, whilst on elerated ground, with the sky only visible bejond him, he will appear larger.

In judging distance practice, so called in contra-distinction to the drill, the soldier is taught to apply the knomledge previously acquired, under the head of drill, by giving a separate individual answer as to his estimation of the distance of men placed at an unknown number of yards from him ; when, providing his answer is within the margin permissible, or, in other vords, somewhere within the prescribed limits of the dangerous space, as already explained, he receires a number of points, in the register lept of the practice, to denote the relative value of his answer.

The foregoing explanation will afford a general clue to the principles upon which the present system of imparting judging distance in England is based - that system is admitted, I beliere, to be the best extant, and is used, rith but slight modification, throughout the entire continent of Europe, and the tro Confederacies of America.

Enough also, I trust, has been said, without further multiplying figures, to show the adrantage derivable from erery soldier being acquainted with erery detril connected with the trajectory of his bullet; the figures here alluded to should be familiar in the mouth of everyone armed with the Enfield, as household words; for, though it is true that instruments hare been designed for the computation of distances, in the excitement of battle the soldier would not be capable of using such, and all instruments are thus far unsatisfactory either from giving an inexact approximation, being too complicated, or requiring too much time to use them.

After all, an approximation such as the practised cye can giro is most to be desired, and there are few men indeed who camnot with a little labour and care attain such proficiency in judging distance as will at least cnable trem to strike an object the size of a battalion in column at a distance of 900 or 1000 yards.

Fired with the elcration necessary for 900 jards, the Enfield bullet actually acquires a height of about 50 fect before culminating, and hence the currature of the latter part of its track is so great that in a mensure it may be said to appronch the rertical, nnd herein lies the difficulty of obtaining accurate shooting with the Enfield rifle at this and other long ranges; we hare, as it vere, not only to fire at but into an object, the bullet has to be dropped on a man's shalo in order to hit him, so that the slightest possible crror in the matter of cleration or taking aim is at once fatal; a finer sight than usual will cause the bullet to fall short of the mark, while a fuller sight will eause it to fall orer and bejond. Mroreover, we now lose the eflect of ricochet-fire owing to the high angle at which the bullet strikes the ground.

Eren accorling to the Hythe average at this distance, only 13 ont of erery 100 shots fired at a target 6 fect ligh and 12 fect wide, ever take effect. - Increasing the wilth of the target aids us comparatively little, the difficulty is one of eleration, not direction. It is owing to this that none but highly trained soldiers, marksmen in every sense of the word, shonld erer 
be sllowed to firc at long distances (such as 700, 800, and 900 yards) at snaller objects than a column of men or troops, whose depth would make up in some degree for any misapprecintion of distance, or effect of faulty aim.

To drop a ball from an Enfield rifle on to a recomnoitring staff-officer at 900 yards, could be done, probably, by only a fer men in the regiment; but if a lostile battalion should endearour to alrance from 900 fards dietance to 300 yards, every man in a regiment onght to contribnte lis quota towards their destruction, for there rould be no need of nicely timing the discharge or of minute accuracy of elevation.

It therefore becomes apparent that the adrantages to be derived from a low or flat trajectory cannot be over estimated; all our difficulty in shooting is owing to the bullet moring in a curred line, and if it wrere possible to have a rifle to project a bullet in a line, parallel, or nearly so, to the earth's surface, I need hardly say, judging distance would be no longer necessary, and schools of musketry become to a great extent superfloous. The Enfield rifle is surpassed in this respect by rifles which hare emanated from private manufacturers, and by none more so than that of Wr. Whitrorth, which, so far as relinble data can be taken, has the flattest trajectory known.

To put the comparative merits of these two reapons in the matter of trajectories in more familiar and definite terms, I may state, that, whereas the curre described by the Enfield bullet at 500 yards (fired at an angle of $1^{\circ} 30^{\prime}$ ) attains a height of 15 feet at its highest part, the Whitworth at this range (at an angle of $1^{\circ} 15^{\prime}$ ) only acquires a height of 8 fect 6 inches, in other roords, the trajectory of the Whitmorth, at this range, is more than 40 per cent. lower, and thereforo better, than that of the Enfield, and the practical corollary which flows forth from this fact is, that if a body of caralry were to charge riflemen (infantry) from a position 500 yards off, the Whitrorth bullet aimed for that distance would hit them in any part of its flight, while the Enfield, at the centro of its curve, must whistle harmlessly over their heads, thougl a first-class marksman fired the shot.

Although the highly curred trajectory of the Enfield-rifle at long ranges must obviously bo regarded as a decided fault and a weakness, so to speak, in its construction, yet certain exceptional circumstances may arise, under which this very fault may be turned to positive advantage.

In actual warfare it continually happens that troops allance to storm a breach or attack an enemy in position, covered by the fire of artillery. This was done, for example, with admirable result, at the seige of San Seliastian, in Spain, and again, in more recent times, with a like success, at the capturing of the Taku Forts the other day in China; in the former instance, howitzers were for the most part made use of; in the latter instance, $\Lambda$ rmstrong rifled field-guns, fired with a smaller charge and increased cleration. Now, let ns put artillery on one side, and, assuming that it has been prevented coming " to the front," owing to the nature of the ground, want of horses, or some of the other hundred and one impedimental accidents liable to occurrence in the best regulated mar, let us see, whether under such circumstances the Enfield might not, in a modified nanuer, be made to do the work of the big guns.

We will suppose that a small brigade of infantry consisting, say, of three regiments, with a respectire effective strength of $600 \mathrm{men}$, armed with 
Enfields, but unsupported by artillery, have to attack an open ficld-work which has been thromn up and oceupied by the enemy.

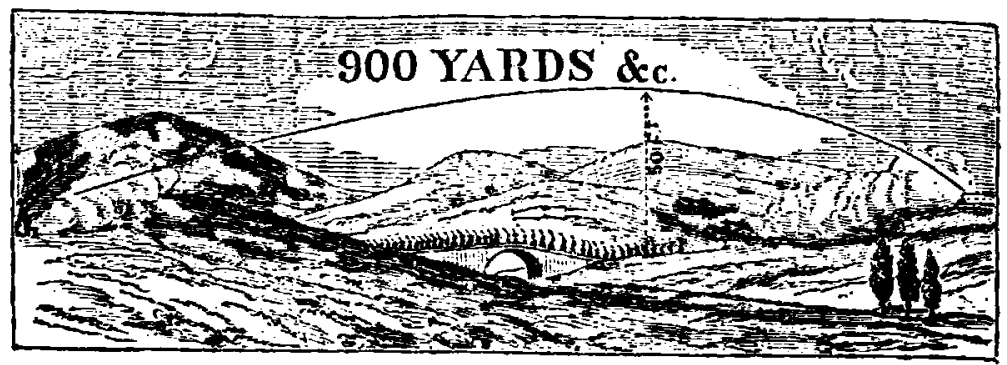

The work rests on the crest of a hill, the natural slope of which serres as a glacis, girt at its base by a small stream spamed by a bridge, which, owing to the nature of the surrounding country, constitutes the only practicable appronch; the attncking force adrances in colmm across the opposite declivity (or plain) till within range of the enemy's artillery, when it deploys into lime, and a further adrance is made till within some 900 or 1000 yards of the enemy's work, and here, while one half of the force continues to more on to the assault, the other half commence firing rolley after volley into the open area of this ficld-work, orer the heads of their comrades at the easy rate of tro rolleys per minute, thus $1,200 \mathrm{men}$ rould in ten minntes project no less than 24,000 Enfield bullets into the Redam, into a comparatively circumscribed area ; beneath such a hailstom of lead, it wonkd be impossible for human life to exist, and the storming party wonld clamber orer the parapet only to find guus deserted and gumners hor's de combat.

Nor must it he supuosed that the occurrence of an incident such as I have attempted to describe, is beyond the limits of probability or fact, on the contrary, it is authenticated that at least upon tro occasions cluring the suppression of the Indian mutiuy, a similar alaptation of the Enfield rifle was made under vearly parallel cireumstances to those here related. But, eren admitting that the chances of such a combination of circumstances recurring are few and far betrreen, and learing ont of riew the possibility of partially covering the adrance of troops by means of Enfeld rifle fire; what has been said will at least serve to show that the vertical fire of the Enfield at long ranges may bo made tse of with admirable effect for sicge purposes, where a large aren is presented for firing into, for enfilading a redoubt, or hindering a working party throwing up a fichl-rrork; nor must it be supposed that the range of the Enficld rifle for purposes of this lind is limited to 900 yarls; it is capable, in reality, of being used effectirely at mueh longer distances (the soldier, with that view, haring merely to raiso his ere as much alore the back-sight as the distance appears to justiff, still keeping the foresight aligned with the object). Instances are on record in this country of the Enfield having lilled shcep 2000 yards off, and at New Zealand, during the present war, in the country of the Tarnnakis, one was fired with effect from a fixed rest with an elevation for 3000 yards. 
After the fall of Serastopol, amongst other things, Russian officers related that their men, when seated smoking in fancied security benenth their doorways, had frequently been struck domn by Enfield bullets, at distances almost fabulons. Its deadly effect at vast distances made it the dread of the Sepors, who termed it "the gun that kills without maling any sound."

Notwithstanding, horrevel, that so many things may be said in farour of the Enficld rifle, partiality must not be suffered to blind us to its defects.

The late Lord Herbert, when Secretary for War, claimed a "ten Jears' life" for the Enfield rifle; experience proves, howerer, that its longerity is eren less than this, and practicians know full rell that long ere that prescribed decade has run its course, the weapon, owing to an inherent susceptibility to the abrasion of the bullet, and the frictional action of the ramrod, especially torrards the muzzle, where the groores are shallowest and barrel weakest, ceases to be a rifle in all sare name. Under such circumstances, the economy of continuing the manufacture of this description of rifle, and its retention as a service arm, may well be called in question. Any scruples of an economical kind, howerer, must gire way to doubts of a graver character, when the comparative efficiency of the reapon is considered.

Without entering into detail, it may be stated that a careful inrestigation will satisfy any one that this particular arm, if it has not already become inferior to that of other nations, is at least greatly inferior to the rifles which have emanated from the private gun factories of this countryrifles which are made use of at every Volnuteer rifle match, to the almost entire exclusion of the military arms.

In effect, the trajectory of the "Enfield" is, practically speaking, too high. At great distances the bullet plunges, and the "daugerous space" is reduced to a fer yards, thus necessitating an claborate system of judging distances.

It is true that a reduction in the height of the trajectory involves, almost as a necessity, a rednction in the bore of the rifle, and against this it is grarely argued, that the calibre of the Enfield conld not be reduced without injuriously affecting its efficiency as a military arm, and that in order to kill a man the projectile must have a diameter of 577 of an inch, and that the Whitworth bullet with a diameter of $\cdot 45$ of an inch is too small for that purpose. This surely is "splitting hairs." One camot but remember that the self-same argument was urged in days past against the introduction of the "Enfield;" and the Dukse of Wellington, who was obstinately wedded to "Brown Bess," stickled to the last for its large bore, and the necessity of maling a big hole in the enemy; so that, had he lired, our men would hare had to fight at Inkerman with smooth-bores versus rifles.

The increased power of penetration surely more than nentralizes any hypothetical disadrantage arising from the reduction in the diameter of the projectile.

At Inkerman, an Enfield bulletwas known to pass through three Russians; and, as at Hythe, in 1857 (vide Report), it was demonstrated that the relativo penetration of the Enfield and Whitworth projectiles was as 4 to 11, it follows, as a consequence, by the simple application of the rule of three, that at Inkerman, where, as every one knows, the Russians were in close voL. VI. 
order, one Whitworth bullet rould hare killed eight Russians, slightly wounding the ninth!

Another argument usually brought forward against the gradual adoption of a rifle with a smaller bore than that of the Enfield is, that it ronld necessitate our having tro sizes of ammunition in the service; but this objection cannot surely be seriously entertained, inasmuch as the cril, if such it can be called, would be merely of a temporary character : moreorer, the exception loses much of its force from tho fact of our artillery having many different sizes of ammunition in use at ono time.

In conclusion, I cannot but express regret, before quitting this subject, that the Volunteers, who were expected by the regular serrice to originate so much of a progressire character as to weapons of war, should hare contented themselres with the common arm of the private soldier, instead of making a strenuous effort to obtain a small-bore breech-loader, with the trajectory so low and flat that the necessity of judging distance would hare been rendered unnecessary, and the close adrance of caralry made impossible.

That in course of time the bore of the Enficld will be further reduced, and that the present system of muzzle-loading will crentually gire way to that of breech-loading, is bejond a doubt, and for the sake of the British soldier let us hope that this good time coming, is not far distant.

An cminent statesman recently remarked, that the spirit of progress of the winetcenth century generally ends in a recurrence to ancient ideas, progress in knowledge and civilization reproduces the contrivances of an age which we style barbarous; the great points sought for in the military rifle of our day are celerity and accuracy - that it should bo celer et certus -be capable of a quick discharge, and up to a reasonable distance possess unerring accuracy. These are the very qualities our worthy forefathers claimed for their long bows 600 years ago; the Old English long bow had a range of 600 jards, and it could shoot 12 times in a minute: we want nothing more in a good breech-loader.

So true it is that "there is nothing new under the sun"-in this very paper, many of my ideas have been gathered from the remarks of others, who have goue before, or are jet alive; but, while making this general and grateful acknowledgment to them, I trust it will not render the substance of these remarks less acceptable at the present time. 